\title{
The role of technological capability in the
} internationalization of the company and new product success: a systematic literature review

\author{
Rodrigo Marques de Almeida Guerra ${ }^{1}$ and Maria Emília Camargo \\ University of Caxias do Sul - UCS, Caxias do Sul, RS, Brazil.
}

ARTICLE DETAILS
Article history:
Received 22 july 2015
Accepted 09 march 2016
Available online in 30 april 2016
Double Blind Review System
Scientific Editors
Eduardo Eugênio Spers

\section{Keywords:}

Technological capability

Moderating effect

Internationalization

New product success

\begin{abstract}
The constant changes in the existing corporate environment require organizations to submit high speed to adapt to hypercompetitive scenarios. Technological capability can promote company internationalization as it enables the formation of strategic partnerships, investment in R\&D, resource sharing, technology transfer, and economies of scale. The aim of this article is to conduct a systematic review of the literature on the role of technological capability in company internationalization and new product success (NPS). It was therefore necessary to analyze 87 articles obtained from four databases. The survey results suggest that technological capability can be used as a moderating variable; technological capability is considered an important element of economic growth; it facilitates company internationalization; can provide NPS; technology transfer assists the formation of technological capability through the tacit knowledge, skills, and competencies of staff; as a rule, export companies have greater technological capabilities. Finally, a theoretical framework, study limitations, and suggestions for future research are proposed.
\end{abstract}

(C) 2016 Internext | ESPM. All rights reserved!

\section{Introduction}

Technological capability has been observed as an important element in the economic growth of a nation, since the development of an enterprise depends on the capability to introduce new products over time. Scant research has been developed involving technological capability and the internationalization of companies from emerging economies, such as Russia, India, Brazil, Mexico, and China (Chittoor \& Ray, 2007; Väätänen, Podmetina \& Pillania, 2009; Dechezleprêtre, Glachant \& Ménière, 2009).

We need to develop new research in emerging market countries to understand new product success (NPS) in international markets, especially if it is associated with obtaining technological capability. Introducing a new pioneer product in the market can increase the success rate. Therefore, it is critical that the organization geographically expands the insertion area of its products through firm internationalization (Duysters \& Hagedoorn, 2000; Schneider, Holzer \& Hoffmann, 2008; Haeussler, Patzelt \& Zahra, 2012; García, Avella \& Fernández, 2012).

However, the company should be cautious with the decision to keep "mature products" and/or generate "new products", because performance portfolios influence companies' financial results. Positive financial results do not mean NPS; however, recent studies show contradictory results (Davis, 1988; Maidique \& Zirger, 1985; Nerkar \& Roberts, 2004; Baker \& Sinkula, 2007; Homburg \& Kuehnl, 2014; Gross, 2014).

The low success rate of new products worries some scholars, perhaps because the success of a new product is considered complex, in other words, it directly involves obtaining financial resources, high development costs, investment risk, a low life cycle in the market, and a rapid release time. Several 
organizations seek to compete in the international market to improve the relationship with it and expand customer numbers.

The aim of this article is to conduct a systematic review of the literature on the role of technological capability in company internationalization and NPS. At the end of the survey, contributions from the following aspects are expected: importance of technological capacity as a moderating variable; technological capacity can be an important element for economic growth, facilitating company internationalization; it could contribute to NPS; technology transfer can help in the formation of technological capacity, particularly in relation to tacit knowledge, skills, and competencies of employees; generally, exporting companies prioritize technological capabilities in order to develop a competitive advantage over rivals. Furthermore, a theoretical framework will be introduced for future application, which contributes to the uniqueness of this research.

The rest of the research is organized as follows: first, a brief theoretical review is developed for technological capability, the firm's internationalization, and new product success. Then we present the methodological procedures, especially in relation to the identification of research sources, application of search terms, and selection of researched articles. Finally, final considerations arising from the research are approached along with limitations and recommendations for future studies.

\section{Theoretical review}

2.1 Technological capability: what it is and what it does

Technological changes are continuously creating challenges and opportunities for the development of new products (Wei, 1995; Cetindamara, Phaal \& Probert, 2009). Technological change is considered as an ongoing process that intends to absorb or create technical knowledge aimed at acquiring external inputs for the firm, skills accumulation, and transforming knowledge into innovation (Lall, 1992).

Technological capability contributes to the achievement of higher levels of economic performance for firms, since it allows incremental improvements from the use of new technologies (Jonker; Romijn; Szirmai, 2006). Access to a wider range of new technology options (Tatikonda \& Stock, 2003) can influence the product cycle time (MontoyaWeiss \& Calantone, 1994), speed of firm innovation (Coombs \& Bierly III, 2006), launch and time to market of new products (Calantone \& Di Benedetto, 2012), product development costs (Hultink \& Robben, 1995), success in developing new products (Tatikonda \& Stock, 2003), and is considered an important component of knowledge and skills for the firm (Tatikonda \& Stock, 2003; Renko, Carsrud \& Brännback, 2009).

Technological capability is the ability of the company to execute any relevant technical function, including the ability to develop new products, processes, and technological knowledge in order to obtain higher levels of organizational efficiency (Tsai, 2004). Through technological capability, the company can gain a competitive edge within the industry, particularly in a high-tech environment (Duysters \& Hagedoorn, 2000; Afuah, 2002; Archibugi \& Coco, 2004; Ortega, 2010), such as the chemical, electronic, or pharmaceutical industry (Schoenecker \& Swanson, 2002; Tsai, 2004; Wong, 2014).

Technological capability is key to gaining competitive advantage (Afuah, 2002; Teece, Pisano \& Schuen, 1997; Tsai, 2004), as multinational companies seek to accelerate the transfer from technology units located in developed countries to its subsidiaries positioned in developing countries (Niosi, 1999; Chakrabarti \& Bhaumik, 2010; Si, Liefner \& Wang, 2013), for example: China (Yin, 1992; Chakrabarti \& Bhaumik, 2010; Li, 2010), Russia (Väätänen, Podmetina \& Pillania, 2009), Mexico, Brazil, and India (Chittoor \& Ray, 2007; Dechezleprêtre, Glachant \& Meniere, 2009). However, depending on the diffusion capability of domestic technologies, the country of origin may have a lower rate of technology internationalization, such as in India (Chittoor \& Ray, 2007; Dechezleprêtre, Glachant \& Meniere, 2009).

Some reasons that can justify advancing technological capability are: the need for developing and maintaining internal capabilities, changes in technologies underlying the control system, R\&D, closer relations with universities, research institutes, and specialized suppliers (Niosi, 1999; Bozeman, 2000; Prencipe, 2000; Terawatanavong et al., 2011; Wang \& Zhou, 2013), development of new technology components, long-term system 
integration capabilities (Prencipe, 2000), and firm internationalization (Kyläheiko et al., 2011).

Technological capability is a positive predictor of product innovation (Renko, Carsrud \& Brännback, 2009), however high levels of technological capability may prevent the product from generating innovation (Zhou \& Wu, 2010). To minimize this impact, investors should look for markets that demonstrate technological expansion potential (the biotech industry, for example) and market innovation (Renko, Carsrud \& Brännback, 2009) through firm internationalization (Garcia, Avella \& Fernandez, 2012).

Intangible resources and technological capability are of great strategic potential for the firm (GarcíaMuiña \& Navas-Lopez, 2007). There is a differentiation in relation to competitors, should seek the transfer of knowledge, intangible asset and difficult to spread to be obtained tacitly (Grant, 1996). For this reason, technological knowledge is presented asymmetrically in organizations (LALL, 1992), being directly associated with the absorption capacity of its employees (Zahra \& George, 2002; García, Avella \& Fernández, 2012; Tzokas et al., 2015) and level of investment in R\&D (Niosi, 1999; Coombs \& Bierly III, 2006).

Capacity absorption can be considered a facilitator or barrier to obtaining technological capability (Cohen \& Levinthal, 1989), because it is directly linked to the speed of innovation of the firm (Lall, 1992). Innovation speed indicates how quickly the company uses new technologies (Coombs \& Bierly III, 2006) and is considered crucial to internationalization (formation of strategic alliances, joint ventures, mergers and acquisitions, for example) (Duysters \& Hagedoorn, 2000; Haeussler, Patzelt \& Zahra, 2012; García, Avella \& Fernández, 2012) and launching innovative products (Hsieh, Tsai \& Hultink, 2006; Hsieh \& Tsai, 2007).

Technological capability is influenced by internal factors (planning and control, market orientation, training, investment in R\&D, manual labor), external factors (government support, purchasing or licensing technology from other companies, and forming strategic alliances to purchase new technologies), and the mode of technology transfer (Zahra, 1996; Madanmohan, Kumar \& Kumar, 2004) must therefore be managed effectively (Tatikonda \& Stock, 2003).
2.2 Contributions of technological capability to firm relations

A better understanding of company internationalization has attracted the attention of the academic community (Garcia, Avella \& Fernández, 2012). Technological capability is crucial to firm internationalization, allowing the formation of joint ventures and strategic alliances, mergers and acquisitions (Duysters \& Hagedoorn, 2000; Haeussler, Patzelt \& Zahra, 2012; García, Avella \& Fernández, 2012), increased productivity (Tsai, 2004; Jonker, Romijn \& Szirmai, 2006; García, Avella \& Fernández, 2012), a level of international competition, entry of foreign investors, increasing exports (Lall, 1992), launching new products (Hsieh, Tsai \& Hultink, 2006; Hsieh \& Tsai, 2007), and profitability. Firm internationalization can be understood as an antecedent variable of technological capability (Tseng \& Chen, 2014).

A high level of technological capability can prevent product innovation due to the U-shaped (Zhou \& Wu, 2010) or bell-shaped relationship (Wu, 2014) that is influenced by the type of innovation (incremental or radical) used by a company (Zhou \& Wu, 2010). This curve is nothing more than the trade-off relationship between costs and benefits, which can result in the decreased success of a new product (Homburg \& Kuehnl, 2014; Gross, 2014). Thus, a high level of technological capability can inhibit the generation of radical innovation, especially in the short term, as it (Zhou \& Wu, 2010) increases globally New Product Development (NPD), costs (Gross, 2014), and increases in investment risk (Zhang, Duysters \& Filippov, 2012).

In this sense, the use of technological resources by exporting firms requires strategic diversification (Kyläheiko et al., 2011; García, Avella \& Fernández, 2012) (Tzokas et al., 2015), strong relationship skills with customers, incremental innovations through the use of new technologies (Jonker, Romijn \& Szirmai, 2006), government incentives (Lall, 1995; Wei, 1995; Wang \& Zhou, 2013), technological planning and control, market orientation, technical manual labor, and infrastructure (Madanmohan, Kumar \& Kumar, 2004).

The higher the strategic flexibility of the company, the greater the technological capabilities associated with innovation will be (Zhou \& Wu, 2010). Thus, internationalization appears to be a good alternative, especially for exporting companies (Garcia, Avella \& 
Fernández, 2012) with high technological capability (Duysters \& Hagedoorn, 2000).

\subsection{Importance of technology transfer}

Several research has been done on technology transfer (Bessant \& Rush, 1995; Niosi, 1999; Bozeman, 2000; Tatikonda \& Stock, 2003; Dechezleprêtre, Glachant \& Meniere, 2009; Costantini \& Liberati, 2014), but further studies should be developed on the basis of contradictory results in developed and developing countries (Yin, 1992). Technology transfer requires operational skills (Yin, 1992) and learning of employees (Lee \& Kim, 1986; Si, Liefner \& Wang, 2013), once the technological knowledge is tacit (Lall, 1992).

Possessing tacit knowledge (Grant, 1996), an organization may accelerate the transfer of technology aimed at financial return and increased competitiveness (Si, Liefner \& Wang, 2013). However, this can lead to greater dependence (Yin, 1992) regarding the technology obtained from the country of origin (Reddy \& Zhao, 1990). The transfer of technology can be realized in several forms, for example, through the formation of joint ventures, from subsidiaries, or through agreements (licensing, compensation or production sharing contracts) (Madanmohan \& Kumar; Kumar, 2004).

The effectiveness of technology transfer depends on the firm's ability to absorb it (Yin, 1992), i.e., the greater the accumulation of technological expertise and market knowledge regarding the product, the greater the chance of a new product succeeding (Nerkar \& Roberts, 2004). The lack of technological capability accumulation (Jonker, Romijn \& Szirmai, 2006) can compromise firm internationalization (Kyläheiko et al., 2011).

The existence of risk associated with NPD should not be overlooked (Ernst, 2002). It can directly affect the transfer of technology, i.e., different modes of technology import can generate different impacts on local technological development (Lall, 1992), especially in relation to international firms' products (Kyläheiko et al., 2011; García, Avella \& Fernández, 2012).

Schneider, Holzer, and Hoffmann (2008) cite the dimensions (geographical access for distribution, technology, and the firm) and barriers (lack of commercial viability, information, and access to capital and institutional models) for the transfer of technology. As a rule, firms have a higher propensity to innovate after importing technology (Wang; \& Zhou, 2013).

Errors or poor planning during technology transfers can cause some problems, such as environmental pollution (Madu, 1989), dependence on a country importing technology (YIN, 1992), the use of inappropriate technology (Calantone \& Di Benedetto, 2012), or selling technology packages (Wei, 1995). One way to reduce the risks and uncertainties about the inadequate transfer of technology is to analyze it as a synergistic process (Madu, 1989).

International technology transfer is considered a key element aimed at growth in developing countries through the use of the Clean Development Mechanism (Lema \& Lema, 2009; Chavez et al., 2015). Developing countries (like Mexico and Brazil) have high levels of international technology transfer, due to the involvement of foreign partners and good local technological capability (Dechezleprêtre, Glachant \& Meniere, 2009).

\subsection{Moderating effect of technological capability}

Several academic papers investigated the moderating effect of technological capabilities (Ortega, 2010; García, Avella \& Fernández, 2012; Haeussler, Patzelt \& Zahra, 2012; Renko, Carsrud \& Brännback, 2009; Wu, 2014; Hsu et al., 2014). Some studies show the technological capability variable with moderating effects (Jabar, Soosay \& Santa, 2011), direct effects (Hsieh \& Tsai, 2007; Tzokas et al., 2015), or both (Renko, Carsrud \& Brännback, 2009).

García, Avella, and Fernández (2012) examined the moderating effect of companies with technological capability on the relationship between exporters and productivity. The research results infer that exporters have a greater propensity to learn than firms holding less technological capability. Ortega (2010) examined variable technological capability in relation to the formation of competitive strategies and firm performance. The study found that technological capability improves the relationship between quality, cost orientation, and performance.

Haeussler, Patzelt, and Zahra (2012) studied the role of strategic alliances in generating partnerships of higher value. The research results indicate that companies with high technological capability made strategic alliances in order to gain knowledge and 
resources. However, companies with low international experience and limited resources are more vulnerable to opportunistic behavior of their partners.

Hsu et al. (2014) investigated the moderating effect of technological capability in relation to the performance of new products and strategic direction. The study results suggest that technological capability strengthens the guidance relationship of the performance of the market, besides affecting financial performance of the company.

Wu et al. (2014) examined the relationship between cooperation with competitors and product innovation with the moderating role of technological capability and strategic alliance with universities and research institutes. The study results show that cooperation with competitors has an inverted Ushaped relationship with innovation of successful products. Strong technological capabilities and collaboration with universities and research institutes has a moderate, negative relationship with the innovation of successful products. Excess cooperation with competitors negatively affects product innovation performance as a result of opportunistic behavior of competitors (Wu et al., 2014).

\subsection{Technological capability and NPS}

NPS in a market depends on the ability of a firm to combine resources (including technology) and turn them into valuable products by facilitating their marketing (Nerkar \& Roberts, 2004). Internationalization and firm speed contribute to greater assertiveness of the launch of new products (Johnson, Piccolotto \& Filippini, 2009), since delays can lead to loss of competitiveness, longer times to market, low levels of coordination, and loss of opportunity (Baker \& Sinkula, 2005; Calantone; Di Benedetto, 2012).

NPS is never guaranteed (Maidique \& Zirger, 1985) but it can be predictable (Cooper \& Kleinschmidt, 1993c), provided that the organization identifies the critical factors that interfere with the success of the new product (Cooper, 1979). Several studies have been developed on NPS (Cooper \& Kleinschmidt, 1993b; Ottum \& Moore, 1997; Maidique \& Zirger, 1984, 1985), where a wide variety of background factors were found to influence the final result of new product performance (MontoyaWeiss \& Calantone, 1994).
Technological capability is just one of the most important antecedents of entrepreneurial companies developing new products (Zahra, 1996; Yu et al., 2014). Innovation can negatively impact NPS (Baker \& Sinkula, 2005), however this finding may be inverted (Kessler \& Bierly, 2002) if the innovation is implemented in order to improve product advantage (Wong, 2012).

Do not confuse NPS with measures of firm financial performance (e.g., profitability), since new products can succeed without necessarily generating positive financial results (Baker \& Sinkula, 2007). While many companies have implemented a number of methods and techniques to improve NPD (Montoya-Weiss \& Calantone, 1994; Barczak, Griffin \& Kahn, 2009), some absolute progress has been developed in recent years to improve the success rate of new products (Barczak, Griffin \& Kahn, 2009).

A dynamic environment requires the development of new products, since highly competitive hostile environments increase the degree of market orientation in an attempt to ensure NPS (Ottum \& Moore, 1997). Companies with strong market orientation, proficiency in NPD, pooling of resources, and cross-functional coordination are more likely to have superior performance in new product designs (Pattikawa, Verwaal \& Commandeur, 2006; Hong, Song \& Yoo, 2013).

Other critical factors that can interfere with NPS are: processing market information (Ottum \& Moore, 1997); product differentiation (Cooper \& Kleinschmidt, 1993a); minor product cycle time (Cooper \& Kleinschmidt, 1993c); product contribution margin; proximity to the new technologies of products and markets (Maidique \& Zirger, 1984); frequency of communication with customers (Maidique \& Zirger, 1985); new product introductions and; guidance for international projects (Cooper \& Kleinschmidt, 1993b), among others.

\section{Methods}

The aim of this article is to conduct a systematic review of the literature on the role of technological capability in company internationalization and NPS. In order to attain this objective, we developed a systematic literature review through six steps: 1) preparing the purpose of the research; 2) selection of research sources; 3) selection and application of search terms; 4) selection of researched articles; 5) construction of the literature review; and 6) synthesis 
and analysis of the results (Rowe, 2014), as shown in Figure 1. A systematic literature review aims to produce a rigorous evaluation of theoretical progress and the most original empirical studies (Wolfswinkel, Furtmueller \& Wilderom, 2013).

In the first step the overall goal of the study was prepared, as previously mentioned. In the second step, we tried to select the font search, in other words, the databases used for selection and downloading of articles. Because this work is an initial study, scientific articles in four databases (Scopus, Web of Science, Springer, and Science Direct) were researched for the following reasons: they are important databases for management and business; two databases have criteria for selecting articles by the number of citations (Scopus and Web of Science); accessibility for consultation and the downloading of articles.

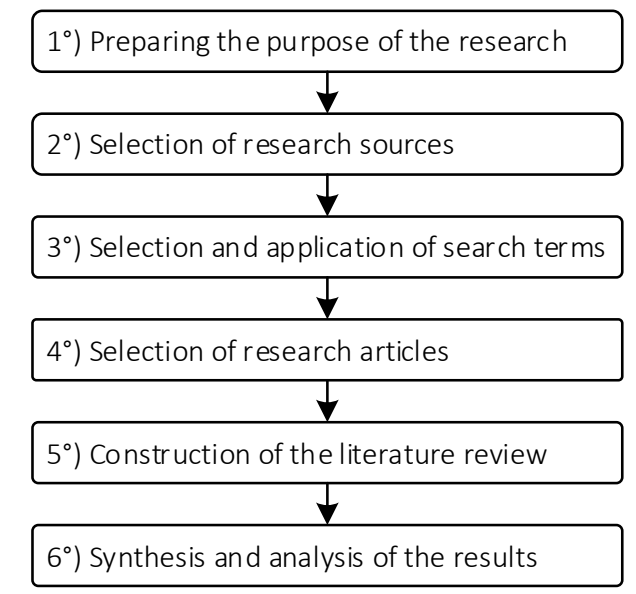

Fig. 1

Stages of systematic literature review

Source: Authors

The third step was the choice of search terms, which is carried out in three phases. The first search phase involved research for the following keywords: "technological capability", "new product", "internationalization", and "success of new product". The second search phase used keywords related to the investigated theme such as: "moderate", "moderating", "moderation", "technological capability", "technology transfer", and "success".

The third stage involved the preparation of new articles through other databases (for example: Web of Science, Springer and Science Direct) in order to increase the number of researched items. The three phase of article identification used the same search criteria ("title" or "abstract" or "keyword" or "titleabstract-keyword"). Additional articles were included in the survey in order to clarify some concepts and variables.

The fourth stage sought to select the researched articles. For this, it was necessary to perform six steps: i) reading the title of the articles; ii) reading the summaries; iii) automatic exclusion of duplicate or inaccessible articles; iv) downloading the articles available; v) reading of the relevant articles, i.e., with the most citations (Scopus and Web of Science); and vi) reading the latest articles (Scopus, Springer, and Science Direct). The total number of reviewed articles was 87 publications.

The fifth step was the preparation of the literature review with a brief conceptual overview, the main gaps, and convergent/divergent results in order to allow a better reflection on the subject investigated. The last step of the research process involved the development of the synthesis and analysis of results related to the following topics: study limitations, further research, and closing remarks. The list of the most important articles pioneer is found in appendix A.

\section{A theoretical model}

This topic is intended to suggest propositions based on the theoretical framework developed and instituted.

\section{$\mathrm{P} 1$ : There is a positive relationship between firm internationalization and NPS}

Currently, to achieve success in the competitive environment, organizations are increasingly developing new products for international markets (De Brentani \& Kleinschmidt, 2004). The formation of strategic alliances, for example, can be important for product differentiation in global markets (Rao, 2001).

High-tech companies are seeking internationalization in order to obtain knowledge and resources aimed at NPS (Haeussler, Patzelt \& Zahra, 2012). Internationalization has a positive impact on company performance (Väätänen, Podmetina \& Pillania, 2009), however, this relationship was not perceived clearly like New Product Success.

The development of new products has become an international activity (Cooper \& Kleinschmidt, 1993a). Companies operating internationally have greater profitability and productivity compared to companies selling products only in the domestic market (Väätänen, Podmetina \& Pillania, 2009). 
Firm internationalization contributes to the emergence of new products, even if they present no better financial performance initially (Si, Liefner \& Wang, 2013). The diversification of a company's product portfolio - if it operates in the international market - increases the chances of selling the products in new markets (Zahra, 1996; Kang \& Montoya, 2014), thus contributing to an increase in NPS rates (Ernst, 2002; Nerkar \& Roberts, 2004).

The highly competitive environment encourages organizations to guide international projects, since keeping a product only in the domestic market can inhibit NPS through the high cost required for its development (Cooper \& Kleinschmidt, 1993b; Li, Nicholls \& Roslow, 1999).

\section{P2: Technological capability positively moderates the relationship between firm internationalization and NPS}

Technological capability can be defined as the capability to intensive knowledge to jointly mobilize different resources to enable the firm to develop innovative products of success through the implementation of competitive strategies and value creation in a given environment (García- Muiña \& Navas-Lopez, 2007).

Therefore, it is necessary that a firm seeks internationalization (Garcia, Avella \& Fernández, 2012), since it will open new markets (De Brentani \& Kleinschmidt, 2004), increasing the chances of successful innovations (Markman et al., 2005), and therefore the higher success rate of new products (Ernst, 2002). The search for maximizing economies of scale and R\&D are needed for both domestic markets and for exporting companies (Li, Nicholls \& Roslow, 1999).

Innovation is essential for exporting companies (Zhang, Jiang \& Zhu, 2015). Therefore, it is necessary that a firm has resources and capabilities needed to achieve innovation (Nerkar \& Roberts, 2004; Hsieh \& Tsai, 2007), a technological capability (Lall, 1992; Teece, Pisano; Schuen 1997; Duysters; Hagedoorn, 2000; Afuah, 2002). Thus, so there is NPS (Davis, 1988; Maidique \& Zirger, 1985; Nerkar \& Roberts, 2004; Gross, 2014), it takes the firm to become international (Duysters \& Hagedoorn, 2000; Haeussler, Patzelt \& Zahra, 2012; García, Avella \& Fernández, 2012), i.e., potentially reach consumer markets (Zhang, Duysters \& Filippov, 2012; Kang \& Montoya, 2014).
The generation of new ideas is critical to the development of new products (Cooper \& Kleinschmidt, 1993b), however local competition can inhibit obtaining insight on international products, restrict company focus to the local market segment only (Cooper \& Kleinschmidt, 1993b; Li, Nicholls \& Roslow, 1999). In this sense, the local operations of the firm can be a strategic limiter, affecting NPS and the intensive use of technological capability by the company.

Several studies have technological capability as a moderating variable (Ortega, 2010; García, Avella \& Fernández, 2012; Haeussler, Patzelt \& Zahra, 2012; Gross, 2014; Renko, Carsrud \& Brännback, 2009; Wu, 2014; Hsu et al., 2014). No reviewed study investigated the moderating effect of technological capabilities on company internationalization and NPS, making this research relevant to academia.

From this systematic literature review, it was possible to establish a schematic representation of the proposed theoretical framework (Figure 2) as well as theoretical support for each of the developed propositions (as already mentioned). The moderating effect of technological capabilities has been commented on in topic 2.4 of this study.

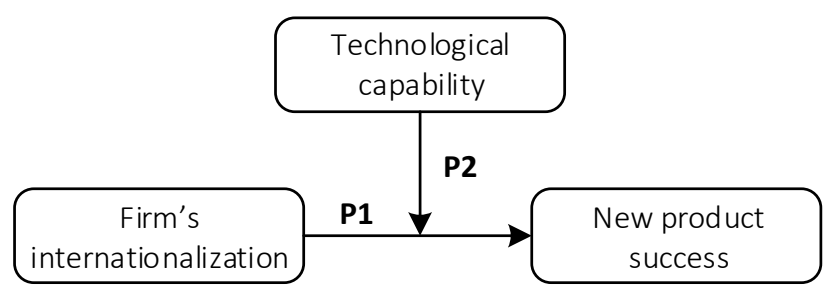

Figure 2. Theoretical framework proposal Source: Authors

\section{Conclusion}

This research led to four important theoretical contributions. The first concerns the importance of a better understanding about the new product success in international markets, as presented by Li, Nicholls, and Roslow (1999). The second contribution indicates that there is theoretical evidence for the moderating effect of technological capacity, as argued by Ortega (2010), García, Avella, and Fernández (2012), Haeussler, Patzelt, and Zahra (2012), Renko, Carsrud, and Brännback (2009), Wu (2014), and Hsu et al. (2014). The third theoretical contribution refers to the importance of technology transfer for the formation of technological capability. The need for 
effective control over the transfer of technology can interfere with the firm's decision to internationalize, and hence, the success of new products as set out by Lall (1992), Yin (1992), Wei (1995), Madanmohan, Kumar, and Kumar (2004), Tatikonda and Stock (2003), Väätänen, Podmetina, and Pillania (2009), and Haeussler, Patzelt, and Zahra (2012). The fourth theoretical contribution indicates the uniqueness of the proposed framework. Throughout the literature review, it was noted that the academic literature is quiet regarding the composition of the proposed variables (schematic representation).

From the theoretical review developed, it was possible to infer that absorption capacity improves the development of skills and competencies necessary for managing tangible and intangible firm assets. This may provide competitive advantage for the firm in the international market, since new markets can generate leads, increasing the chances of NPS.

The existence of the U-shaped trade-off relationship between product costs and benefits can impair the success of a new product. Strong technological capabilities can inhibit the release of new products, increase NPD costs, increase the risk of investment, and generate negative results. In this sense, it is important that the firm expands and builds tighter relationships with potential customers, creating new consumer markets through the company's internationalization.

The moderating effect of the technological capability variable is shown by previous articles, but further studies are needed to generate more precise, clear, and robust results. Inaccurate results can happen for a few reasons: the use of different analytical elements influencing the strength of the moderating variable technological capability; the sample size of the study; geographical restriction of the search and segment; size of the companies surveyed; and the complexity of the relationship between the analysis variables.

The dimensions (geographical access for distribution, technology, and the firm), barriers (lack of commercial viability, information, access to capital, and institutional models), internal factors (planning and control, market orientation; training; R\&D investment, and manual labor), external factors (government support, purchasing or licensing of technology from other companies, and forming strategic alliances to acquire new technologies), and the order and importation of technology can influence the technological capability of the company and should be properly managed.

Company internationalization is important to the launch of new products and contributes to their success. Overall, export companies have greater technological capability compared to non-exporters. The firm's performance enhances the release of new products in the domestic market and reduces product life cycle time, i.e., they are more likely to succeed in the international market.

Thus, higher capability and the speed of innovation can influence the final cost of the product. As a rule, incremental innovations generate less impact (resistance) in consumer markets, because the benefits of the product are more visible to customers.

The main limitation of this study is that it only used four databases (Scopus, Web of Science, Springer, and Science Direct). One could further expand the sources of research (new databases, books, theses, dissertations, etc.) in order to identify additional studies.

Suggestions for future research are in line with the revised theoretical framework, which can be summarized as follows: i) proposed framework should be tested to verify the theoretical findings shown in this study; ii) further research should be carried out with technological capability as a mediating variable and as a direct effect; iii) it should perform further study on technology transfer, since it affects with technological capability; iv) carry out new studies involving the moderating effect of technological capabilities on the direct relationship between strategic direction and firm performance; v) expand studies on technological variables such as, technological turbulence, technological complexity, and speed technology; vi) develop new research involving the direct relationship between company internationalization and NPS, which may become more obvious factors that contribute to the successful launch of new products in foreign markets; and vii) develop new studies on how market orientation and innovation speed can generate important contributions for firm performance.

Finally, the authors gratefully acknowledge the contributions of the reviewers. 


\section{References}

- AFUAH, A. (2002) Mapping technological capabilities into product markets and competitive advantage: the case of cholesterol drugs. Strategic Management Journal, 23 (2), p. 171-179. DOI: 10.1002/smj.221

- $\quad$ ARCHIBUGI, D.; COCO, A. (2004) A new indicator of technological capabilities for developed and developing countries (ArCo). World Development, 32 (4), p. 629-654. doi:10.1016/j.worlddev.2003.10.008

- BAKER, W. E.; SINKULA, J. M. (2005) Market orientation and the new product paradox. The Journal of Product Innovation Management, v. 22, n. 6 , p. 483-502. DOI: 10.1111/j.15405885.2005.00145.x

- BAKER, W. E.; SINKULA, J. M. (2007) Does Market Orientation Facilitate Balanced Innovation Programs? An Organizational Learning Perspective. The Journal of Product Innovation Management, 24 (4), p. 316-334. DOI: 10.1111/j.1540-5885.2007.00254.x

- BARCZAK, G.; GRIFFIN, A.; KAHN, K. B. (2009) Perspective: trends and drivers of success in NPD practices: results of the 2003 PDMA best practices study. The Journal of Product Innovation Management, 26 (1), p. 3-23. DOI: 10.1111/j.15405885.2009.00331.x

- BESSANT, J.; RUSH, H. (1995) Building bridges for innovation: the role of consultants in technology transfer. Research policy, 24 (1), p. 97-114. doi:10.1016/0048-7333(93)00751-E

- BOzEMAN, B. (2000) Technology transfer and public policy: a review of research and theory. Research policy, 29 (4), p. 627-655. doi:10.1016/S0048-7333(99)00093-1

- CARBOnelL, P.; ROdRigueZ, A. I. (2006) Designing teams for speedy product development: The moderating effect of technological complexity. Journal of Business Research, 59 (2), p. 225-232. doi:10.1016/j.jbusres.2005.08.002

- Calantone, R. J.; DI Benedetto, A. (2012) The role of lean launch execution and launch timing on new product performance. Journal of the Academy of Marketing Science, 40, n. 4, p. 526-538. DOI 10.1007/s11747-011-0258-1

- CetindamAR, D.; PHAAL, R.; PROBERT, D. (2009) Understanding technology management as a dynamic capability: A framework for technology management activities. Technovation, 29 (4), p
237-246.

doi:10.1016/j.technovation.2008.10.004

- CHAKRABARTI, A. K.; BHAUMIK, P. K. (2010) Internationalization of technology development in China: an evaluation using patent data. Journal of Technology Management in China, 5 (2), p. 122140.

DOI: http://dx.doi.org/10.1108/17468771011053153

- ChaVeZ, R.; YU, W.; JACOBS, M.; FYNES, B.; WIENGARTEN, F. (2015) Internal lean practices and performance: The role of technological turbulence. International Journal of Production Economics, 160, p. 157-171. doi:10.1016/j.ijpe.2014.10.005

- CHITTOOR, R.; RAY, S. (2007) Internationalization paths of Indian pharmaceutical firms: A strategic group analysis. Journal of International Management, 13 (3), p. 338-355. doi:10.1016/j.intman.2007.05.008

- COHEN, W. M.; LEVINTHAL, D. A. (1989) Innovation and learning: the two faces of R\&D. The Economic Journal, 99 (397) p. 569-596. DOI: $10.2307 / 2233763$

- COSTANTINI, V.; LIBERATI, P. (2014) Technology transfer, institutions and development. Technological Forecasting and Social Change, 88, p. 26-48. doi:10.1016/j.techfore.2014.06.014

- COOMBS, J. E.; BIERLY III, P. E. (2006) Measuring technological capability and performance. $R$ \& $D$ Management, v. 36, n. 4, p. 421-438. DOI: 10.1111/j.1467-9310.2006.00444.x

- COOPER, R. G.; KLEINSCHMIDT, E. J. (1993a) Major New Products: What distinguishes the winners in the chemical industry? The Journal of Product Innovation Management, 10 (2), p. 90-111. doi:10.1016/0737-6782(93)90002-8

- COOPER, R. G.; KLEINSCHMIDT, E. J. (1993b) NewProduct Success in the chemical industry. Industrial Marketing Management, 22 (2) , p. 8599. DOI:10.1016/0019-8501(93)90034-5

- COOPER, R. G.; KLEINSCHMIDT, E. J. (1993c) Screening New Products for potencial winners. Long Range Planning, 26 (6), p. 74-81. DOI:10.1016/0024-6301(93)90208-W

- DE BRENTANI, U.; KLEINSCHMIDT, E. J. (2004) Corporate Culture and Commitment: Impact on Performance of International New Product Development Programs. The Journal of Product Innovation Management, 21 (5) p. 309-333. DOI: 10.1111/j.0737-6782.2004.00085.x 
- DECHEZLEPRÊTRE, A.; GLACHANT, M.; MÉNIÈRE, Y. (2009) Technology transfer by CDM projects: A comparison of Brazil, China, India and Mexico. Energy policy, 37 (2), p. 703-711. DOI:10.1016/j.enpol.2008.10.007

- DAVIS, J. S. (1988) New Product Success \& Failure: Three Case Studies. Industrial Marketing Management, 17 (2), p. 103-109. doi:10.1016/0019-8501(88)90012-0

- DUYSTERS; G.; HAGEDOORN, J. (2000) Core competences and company performance in the world-wide computer industry. The Journal of High Technology Management Research, 11 (1), p. 7591. DOI:10.1016/0019-8501(88)90012-0

- ERNST, H. (2002) Success factors of new product development: a review of the empirical literature. International Journal of Management Reviews, 4 (1), p. 1-40. DOI: 10.1111/14682370.00075

- garcía, F.; AVelLA, L.; fernández, E. (2012) Learning from exporting: The moderating effect of technological capabilities. International Business Review, $21 \quad$ (6), p. 1099-1111. DOI:10.1016/j.ibusrev.2011.12.001

- GARCíA-MUIÑA, F. E.; NAVAS-LÓPEZ, J. E. (2007) Explaining and measuring success in new business: The effect of technological capabilities on firm results. Technovation, 27 (1), p. 30-46. DOI:10.1016/j.technovation.2006.04.004

- GRANT, R. M. (1996) Toward a knowledge-based theory of the firm. Strategic Management Journal, 17 (número especial), p. 109-122. DOI: $10.1002 /$ smj.4250171110

- GROSS, U. (2014) Fighting the fire: improvisational behavior during the production launch of new products. International Journal of Operations \& Production Management, 34 (6), p. 722-749. DOI: http://dx.doi.org/10.1108/IJOPM-08-2012-0306

- haeussler, C.; PATZelt, H.; ZAHRA, S. A. (2012) Strategic alliances and product development in high technology new firms: The moderating effect of technological capabilities. Journal of Business $\begin{array}{llll}\text { Venturing, } 27 & \text { (2) } & \text { p. } 217-233 .\end{array}$ DOI:10.1016/j.jbusvent.2010.10.002

- HOMBURG, C.; KUEHNL, C. (2014) Is the more always better? A comparative study of internal and external integration practices in new product and new service development. Journal of Business $\begin{array}{llll}\text { Research, } 67 & \text { (7), p. 1360-1367. }\end{array}$ DOI:10.1016/j.jbusres.2013.08.017

- HONG, J.; SONG, T. H; YOO, S. (2013) Paths to success: how do market orientation and entrepreneurship orientation produce new product success?. Journal of Product Innovation Management, 30 (1), p. 44-55. DOI: 10.1111/j.1540-5885.2012.00985.x

- HSIEH, M-H.; TSAI, K-H. (20070 Technological capability, social capital and the launch strategy for innovative products. Industrial Marketing Management, $36 \quad$ (4), p. 493-502. DOI:10.1016/j.indmarman.2006.01.002

- HSIEH, M-H.; TSAI, K-H.; HULTINK, E. J. (2006) The relationships between resource configurations and launch strategies in Taiwan's IC design industry: An exploratory study. The Journal of Product Innovation Management, 23 (3), p. 259273. DOI: $10.1111 / j .1540-5885.2006 .00197 . x$

- HULTINK, E. J.; ROBBEN, H. S. J. (1995) Measuring new product success: the difference that time perspective makes. Journal of Product Innovation Management, 12 (5), p. 392-405. DOI: 10.1111/1540-5885.1250392

- JABAR, J.; SOOSAY, C.; SANTA, R. (2011) Organisational learning as an antecedent of technology transfer and new product development: A study of manufacturing firms in Malaysia. Journal of Manufacturing Technology Management, 22 (1), p. 25-45. DOI: http://dx.doi.org/10.1108/17410381111099798

- JONKER, M.; ROMIJN, H.; SZIRMAI, A. (2006) Technological effort, technological capabilities and economic performance: A case study of the paper manufacturing sector in West Java. Technovation, 26 (1), p. 121-134. DOI:10.1016/j.technovation.2004.10.002

- JOHNSON, W. H.; PICCOLOTTO, Z.; FILIPPINI, R. (2009) The impacts of time performance and market knowledge competence on new product success: an international study. IEEE Transactions on Engineering Management, 56 (2), p. 219-228. DOI: 10.1109/TEM.2008.2009789

- KANG, W.; MONTOYA, M. (2014) The Impact of Product Portfolio Strategy on Financial

- Performance: The Roles of Product Development and Market Entry Decisions. Journal of Product Innovation Management, 31 (3), p. 516-534. DOI: 10.1111/jpim.12111

- KESSLER, E. H.; BIERLY III, P. E. (2002) Is faster really better? An empirical test of the implications of innovation speed. IEEE Transactions on Engineering Management, 49 (1), p. 2-12. DOI: 10.1109/17.985742

- KYLÄHEIKO, K.; JANTUNEN, A.; PUUMALAINEN, K.; SAARENKETO, S.; TUPPURA, A. (2011) Innovation 
and internationalization as growth strategies: The role of technological capabilities and appropriability. International Business Review, 20 (5), p. 508-520. doi:10.1016/j.ibusrev.2010.09.004

- LALL, S. (1992) Technological Capabilities and Industrialization. World Development, 20 (2), p. 165-186. DOI:10.1016/0305-750X(92)90097-F

- LEE, J.; KIM, H-B. (1986) Determinants of new product outcome in a developing country: A longitudinal analysis. International Journal of Research in Marketing, 3 (3), p. 143-156. DOI:10.1016/0167-8116(86)90020-0

- LEMA, A.; LEMA, R. (2013) Technology transfer in the clean development mechanism: Insights from wind power. Global Environmental Change, 23 (1), p. 301-313. DOI:10.1016/j.gloenvcha.2012.10.010

- LI, T.; NICHOLLS, J. A. F.; ROSLOW, S. (1999) The relationships between market-driven learning and new product success in export markets. International Marketing Review, 16 (6), p. 476-503. DOI: 10.1108/02651339910300459

- MADANMOHAN, T. R.; KUMAR, U.; KUMAR, V. (2004) Import-led technological capability: a comparative analysis of Indian and Indonesian manufacturing firms. Technovation, 24 (12), p. 979-993. DOI:10.1016/S0166-4972(03)00030-0

- MADU, C. N. (1989) Transferring Technology to Developing Countries Critical Factors for Success. Long Range Planning, 22 (4), p. 115-124. DOI:10.1016/0024-6301(89)90089-7

- MAIDIQUE, M. A.; ZIRGER, B. J. A study of success and failure in product innovation: the case of the US electronics industry. IEEE Transactions on Engineering Management, v. 31, n. 4, p. 192-203, 1984. DOI: 10.1109/TEM.1984.6447537

- MAIdiQue, M. A.; ZIRGER, B. J. (1985) The new product learning cycle. Research Policy, 14 (6), p. 299-313. DOI:10.1016/0048-7333(85)90001-0

- MARKMAN, G. D.; GIANIODIS, P. T.; PHAN, P. H.; BALKIN, D. B. (2005) Innovation speed: Transferring university technology to market. Research Policy, 34 (7), p. 1058-1075. DOI:10.1016/j.respol.2005.05.007

- MONTOYA-WEISS, M. M.; CALANTONE, R. (1994) Determinants of new product performance: a review and meta-analysis. Journal of Product Innovation Management, 11 (5), p. 397-417. DOI: 10.1111/1540-5885.1150397

- NERKAR, A.; ROBERTS, P. W. (2004) Technological and product-market experience and the success of new product introductions in the pharmaceutical industry. Strategic Management Journal, 25 (8-9), p. 779-799. DOI: 10.1002/smj.417

- NIOSI, J. (1999) The Internationalization of Industrial R\&D From technology transfer to the learning organization. Research Policy, 28 (edição especial), p. 107-117.

- ORTEGA, M. J. R. (2010) Competitive strategies and firm performance: technological capabilities' moderating roles. Journal of Business Research, 63 (12), p. 1273-1281. DOI:10.1016/j.jbusres.2009.09.007

- OTTUM, B. D.; MOORE, W. L. (1997) The role of market information in new product success/failure. Journal of Product Innovation Management, 14 (4), p. 258-273. DOI: 10.1111/1540-5885.1440258

- PATTIKAWA, L. H.; VERWAAL, E.; COMMANDEUR, H. R. (2006) Understanding new product project performance. European Journal of Marketing, 40 (11/12), p. 1178-1193. DOI: http://dx.doi.org/10.1108/03090560610702768

- PRENCIPE, A. (2000) Breadth and depth of technological capabilities in CoPS: the case

- of the aircraft engine control system. Research Policy, 29 (7-8), p. 895-911. DOI:10.1016/S00487333(00)00111-6

- RAO, P. M. (2001) The ICT revolution, internationalization of technological activity, and the emerging economies: implications for global marketing. International Business Review, 10 (5), p. 571-596. DOI:10.1016/S0969-5931(01)00033-6

- REDDY, N. M.; ZHAO, L. (1990) International technology transfer: A review. Research Policy, 19 (4) p. 285-307. DOI:10.1016/00487333(90)90015-X

- RENKO, M.; CARSRUD, A.; BRÄNNBACK, M. (2009) The Effect of a Market Orientation, Entrepreneurial Orientation, and Technological Capability on Innovativeness: A Study of Young Biotechnology Ventures in the United States and in Scandinavia. Journal of Small Business Management, 47 (3), p. 331-369. DOI: 10.1111/j.1540-627X.2009.00274.x

- ROdRígueZ-PINTO, J.; CARBONELL, P.; RODRÍGUEZ-ESCUDERO, A. I. (2011) Speed or quality? How the order of market entry influences the relationship between market orientation and new product performance. International Journal of Research in Marketing, 28 (2), p. 145-154. DOI:10.1016/j.ijresmar.2011.02.001

- ROWE, F. (2014) What literature review is not: 
diversity, boundaries and recommendations. European Journal of Information Systems, 23 (3), 241-253.

- SCHNEIDER, M.; HOLZER, A.; HOFFMANN, V. H. (2008) Understanding the CDM's contribution to technology transfer. Energy Policy, 36 (8), p. 2930 2938. DOI:10.1016/j.enpol.2008.04.009

- SCHOENECKER, T.; SWANSON, L. (2002) Indicators of firm technological capability: validity and performance implications. IEEE Transactions on Engineering Management, 49 (1), p. 36-44. DOI: 10.1109/17.985746

- SI, Y.; LIEFNER, I.; WANG, T. (2013) Foreign direct investment with Chinese characteristics: A middle path between Ownership-Location-Internalization model and Linkage-Leverage-Learning model. Chinese geographical science, 23 (5), p. 594-606. DOI: 10.1007/s11769-013-0603-z

- TATIKOndA, M. V.; STOCK, G. N. (2003) Product technology transfer in the upstream supply chain. The Journal of Product Innovation Management, 20 (6), p. 444-467. DOI: $10.1111 / 1540-5885.00042$

- TEECE, D. J.; PISANO, G.; SCHUEN, A. (1997) Dynamic capabilities and strategic management. Strategic Management Journal, 18 (7), 509-533.

- terawatanaVong, C.; WhitWell, G. J.; WIDING, R. E.; O'CASS, A. (2011) Technological turbulence, supplier market orientation, and buyer satisfaction. Journal of Business Research, 64 (8) p. 911-918. DOI:10.1016/j.jbusres.2010.09.003

- TSAI, K-H. (2004) The impact of technological capability on firm performance in Taiwan's electronics industry. Journal of High Technology Management Research, 15 (2), p. 183-195. DOI:10.1016/j.hitech.2004.03.002

- TSENG, C-H.; CHEN, L-T. (2014) Determinants of subsidiary's technological capability - examining the roles of subsidiary - local supplier linkage. Journal of Business \& Industrial Marketing, 29 (5), p. 374-386. DOI: http://dx.doi.org/10.1108/JBIM-06-2012-0094

- TZOKAS, N.; KIM, Y. A.; AKBAR, H.; AL-DAJANI, H. (2015) Absorptive capacity and performance: The role of customer relationship and technological capabilities in high-tech SMEs. Industrial Marketing Management, 47, p. 134-142. DOI:10.1016/j.indmarman.2015.02.033

- VÄ̈̈TÄNEN, J.; PODMETINA, D.; PILLANIA, R. K. (2009) Internationalization and Company Performance: A Study of Emerging Russian Multinationals. Multinational Business Review, 17
(2), p. 157-178. DOI: http://dx.doi.org/10.1108/1525383X200900014

- WANG, Y.; ZHOU, Z. (2013) The dual role of local sites in assisting firms with developing

- technological capabilities: Evidence from China. International Business Review, 22 (1), p. 63-76. DOI:10.1016/j.ibusrev.2012.02.003

- WEI, L. (1995) International Technology Transfer and Development of Technological Capabilities: A Theoretical Framework. Technology in Society, 17 (1), p. 103-120. DOI:10.1016/0160791X(94)00028-C

- WOLFSWINKEL, J. F.; FURTMUELLER, E.; WILDEROM, C. P. M. (2013) Using grounded theory as a method for rigorously reviewing literature. European Journal of Information Systems, 22 (1), 45-55. DOI:10.1057/ejis.2011.51

- WONG, S. K-S. (2012) The influences of entrepreneurial orientation on product advantage and new product success. Journal of Chinese Entrepreneurship, 4 (3), p. 243-262. DOI:

- $\quad$ http://dx.doi.org/10.1108/17561391211262175

- WONG, S. K-S. (2014) Impacts of environmental turbulence on entrepreneurial orientation and new product success. European Journal of Innovation Management, 17 (2), p. 229-249. DOI: http://dx.doi.org/10.1108/EJIM-04-2013-0032

- WONG, S. K-S; TONG, C. (2013) New product success: empirical evidence from SMEs in China. Journal of Business \& Industrial Marketing, 28 (7), p. 589-601. DOI: http://dx.doi.org/10.1108/JBIM-04-2011-0046

- WU, J. (2014) Cooperation with competitors and product innovation: Moderating effects of technological capability and alliances with universities. Industrial Marketing Management, 43 (2), p. 199-209. DOI:10.1016/j.indmarman.2013.11.002

- YIN, J. Z. (1992) Technological Capabilities as Determinants of the Success of Technology Transfer Projects. Technological Forecasting and Social Change, 42 (1), p. 17-19. DOI:10.1016/00401625(92)90070-A

- YU, B.; HAO, S.; AHLSTROM, S. S.; LIANG, D. (2014) Entrepreneurial firms' network competence, technological capability, and new product development performance. Asia Pacific Management, 31 (3), p. 687-704. DOI 10.1007/s10490-013-9365-5 
- $\quad$ ZAHRA, S. A. (1996) Technology strategy and new venture performance: a study of corporatesponsored and independent biotechnology ventures. Journal of business venturing, 11 (4), p. 289-321. DOI:10.1016/0883-9026(95)00128-X

- ZAHRA, S. A.; GEORGE, G. (2002) The net-enable business innovation cycle and the evolution of dynamic capabilities. Information Systems Research, 13 (2), 147-150.

- ZHANG, J.; JIANG, Y.; ZHU, M. (2015) Perceived environmental turbulence, strategic orientations and new product success: A comparative study of SMEs and large manufacturing exporters. Journal of Advances in Management Research, 12 (1), p. 43-54. DOI: 10.1108/JAMR-05-2014-0026

- ZHANG, Y.; DUYSTERS, G.; FILIPPOV, S. (2012) Chinese firms entering Europe Internationalization through acquisitions and strategic alliances. Journal of Science and Technology Policy in China, 3 (2), p. 102-123. DOI: http://dx.doi.org/10.1108/17585521211256973

- ZHOU, K. Z.; WU, Z. (2010) Technological capability, strategic flexibility, and product innovation. Strategic Management Journal, 31 (5), p. 547-561. DOI: 10.1002/smj.830

\section{Appendix A}

List of the main authors identified from the literature review

\begin{tabular}{|c|c|c|}
\hline Author(s) & Article title & Purpose of research / Search problem \\
\hline Yin (1992) & $\begin{array}{l}\text { Technological capabilities as determinants of the } \\
\text { Success of Technology Transfer Projects }\end{array}$ & $\begin{array}{l}\text { To understand empirically the effect of indigenous technological } \\
\text { capability on the performance of technology transfer projects } \\
\text { benefiting companies in a less developed country. }\end{array}$ \\
\hline Lall (1992) & Technological Capabilities and Industrialization & $\begin{array}{l}\text { To analyze the implications for recent industrial strategy on the } \\
\text { technological capabilities within the company and at national level. }\end{array}$ \\
\hline Wei (1995) & $\begin{array}{l}\text { International Technology Transfer and } \\
\text { Development of Technological Capabilities: a } \\
\text { Theoretical Framework }\end{array}$ & $\begin{array}{l}\text { To examine the policy issues in the field of international technology } \\
\text { transfer. }\end{array}$ \\
\hline Tsai (2004) & $\begin{array}{l}\text { The Impact of Technological Capability on Firm } \\
\text { Performance in Taiwan's Electronics Industry }\end{array}$ & $\begin{array}{l}\text { To examine the impact of technological training on company } \\
\text { performance. }\end{array}$ \\
\hline $\begin{array}{r}\text { Madanmohan, } \\
\text { Kumar, and Kumar } \\
(2004)\end{array}$ & $\begin{array}{l}\text { Import-led Technological Capability: a } \\
\text { Comparative Analysis of Indian and Indonesian } \\
\text { Manufacturing Firms }\end{array}$ & $\begin{array}{l}\text { To investigate the critical elements that affect the ability of firms in } \\
\text { developing countries to cultivate technological capacity through } \\
\text { imported technology. }\end{array}$ \\
\hline $\begin{array}{r}\text { Coombs and Bierly } \\
\text { III (2006) }\end{array}$ & $\begin{array}{l}\text { Measuring Technological Capability and } \\
\text { Performance }\end{array}$ & $\begin{array}{l}\text { To demonstrate the theoretical and empirical complexity of } \\
\text { technological capability and firm performance and explain why the use } \\
\text { of different measures can lead to dramatically different results. }\end{array}$ \\
\hline $\begin{array}{l}\text { Hsieh, Tsai, and } \\
\text { Hultink (2006) }\end{array}$ & $\begin{array}{l}\text { The Relationships Between Resource } \\
\text { Configurations and Launch Strategies in Taiwan's } \\
\text { IC Design Industry: an Exploratory Study }\end{array}$ & $\begin{array}{l}\text { To examine the relationship between the configuration of resources } \\
\text { and selection of launch strategies. In addition, investigates the growth } \\
\text { moderating effects of market and competitiveness in the relationship } \\
\text { between the interpolation capabilities and launch strategies. }\end{array}$ \\
\hline $\begin{array}{r}\text { Hsieh and Tsai } \\
(2007)\end{array}$ & $\begin{array}{l}\text { Technological Capability, Social Capital, and the } \\
\text { Launch Strategy for Innovative Products }\end{array}$ & $\begin{array}{l}\text { To investigate the influence of technological capacity and social capital, } \\
\text { two essential resources for innovation in high-tech companies in the } \\
\text { adoption of a strategy of launching innovative products. }\end{array}$ \\
\hline $\begin{array}{l}\text { Chakrabarti and } \\
\text { Bhaumik (2010) }\end{array}$ & $\begin{array}{l}\text { Internationalization of Technology Development } \\
\text { in China: an Evaluation Using Patent Data }\end{array}$ & $\begin{array}{l}\text { To study the development of technology in China from the perspective } \\
\text { of the R\&D globalization of activities. }\end{array}$ \\
\hline $\begin{array}{l}\text { García, Avella, and } \\
\text { Fernández (2012) }\end{array}$ & $\begin{array}{l}\text { Learning from Exporting: The Moderating Effect } \\
\text { of Technological Capabilities }\end{array}$ & $\begin{array}{l}\text { To analyze empirically whether a firm's technological capabilities } \\
\text { (proxied by its relative R\&D expenditures) affects its ability to learn } \\
\text { from interaction with foreign agents. }\end{array}$ \\
\hline $\begin{array}{l}\text { Haeussler, Patzelt, } \\
\text { and Zahra (2012) }\end{array}$ & $\begin{array}{l}\text { Strategic Alliances and Product Development in } \\
\text { New High-Technology Firms: the Moderating } \\
\text { Effect of Technological Capabilities }\end{array}$ & $\begin{array}{l}\text { How can new firms maximize the benefits of these alliances while } \\
\text { reducing their risks? }\end{array}$ \\
\hline Hsu et al. (2014) & $\begin{array}{l}\text { Strategic Orientation and New Product } \\
\text { Performance: the Roles of Technological } \\
\text { Capability }\end{array}$ & $\begin{array}{l}\text { This study aims to fill the gap in marketing literature by addressing how } \\
\text { technological capability moderates the strategic orientation of new } \\
\text { product performance. }\end{array}$ \\
\hline Yu et al. (2014) & $\begin{array}{l}\text { Entrepreneurial Firms' Network Competence, } \\
\text { Technological Capability, and New Product } \\
\text { Development Performance }\end{array}$ & $\begin{array}{l}\text { How do entrepreneurial firms leverage network competences and } \\
\text { technological capability to enhance their new product development } \\
\text { performance in a turbulent environment? }\end{array}$ \\
\hline
\end{tabular}

Source: Prepared by the authors 


\title{
About the Authors
}

- Rodrigo Marques de Almeida Guerra Doctorate in Administration from the Catholic Pontifical University of Rio Grande do Sul (PUC/RS). Coordinator of the Administration Graduate Course at the Núcleo Universitário de Farroupilha of University of Caxias do Sul - UCS/RS, Brazil. E-mail: rmaguerra@ucs.br

- Maria Emília Camargo has Doctorate in Production Engineering from the Federal University of Santa Catarina UFSC/SC. Also is Professor and Coordinator of the Master's and Doctorate Administration programs at the University of Caxias do Sul - USC. E-mail: mariaemiliappga@gmail.com

\section{O papel da capacidade tecnológica para a internacionalização da firma e sucesso de novos produtos: Uma revisão sistemática da literatura}

\author{
Rodrigo Marques de Almeida Guerra e Maria Emília Camargo \\ Universdade de Caxias do Sul - UCS, Caxias do Sul, RS, Brasil.
}

\section{DETALHES DO ARTIGO}

\section{Histórico do artigo:}

Recebido em 22 de julho de 2015

Aceito em 09 de março de 2016

Disponível online em 30 de abril de 2016

Sistema de Revisão "Double Blind Review"

Editor científico:

Eduardo Eugênio Spers

\section{Palavras-chaves:}

Capacidade tecnológica

Efeito moderador

Internacionalização

Sucesso de novos produtos

\section{RESUMO}

As constantes mudanças existentes no ambiente corporativo exigem que as organizações apresentem alta velocidade de adaptação aos cenários hipercompetitivos. A capacidade tecnológica pode favorecer a internacionalização da empresa, uma vez que possibilita a formação de parcerias estratégicas, investimento em $P \& D$, compartilhamento de recursos, transferência de tecnologia e economia de escala. O objetivo deste artigo é realizar uma revisão sistemática da literatura sobre o papel da capacitação tecnológica para a internacionalização da empresa e sucesso de novos produtos. Para tanto, foi necessário analisar 87 artigos obtidos a partir de quatro bases de dados. Os resultados da pesquisa sugerem que a capacidade tecnológica pode ser utilizada como variável moderadora; capacidade tecnológica é considerada um importante elemento de crescimento econômico; facilita a internacionalização da empresa; pode proporcionar o sucesso de novos produtos; a transferência de tecnologia auxilia na formação de capacidade tecnológica, por meio do conhecimento tácito, habilidades e competências dos funcionários; em regra, empresas exportadoras apresentam maior capacidade tecnológica. Por fim, foi proposto um framework teórico, limitação do estudo e sugestões para pesquisas futuras.

(C) 2016 Internext | ESPM. Todos os direitos reservados! 